\title{
Assessment of the effectiveness of liquid hot water and steam explosion pretreatments of fast-growing poplar (Populus trichocarpa) wood
}

\author{
Andrzej Antczak ${ }^{1}$ (D) Jan Szadkowski ${ }^{1} \cdot$ Dominika Szadkowska $^{1}$. \\ Janusz Zawadzki ${ }^{1}$
}

Received: 28 April 2021 / Accepted: 20 November 2021 / Published online: 6 December 2021

(C) The Author(s) 2021

\begin{abstract}
In this paper, the influence of physicochemical pretreatment methods on the chemical composition, enzymatic hydrolysis efficiency and porosity of fast-growing Рориlus trichocarpa wood was compared. Among the pretreatment methods, the liquid hot water (LHW) and steam explosion (SE) were used, which were performed at three different temperatures $\left(160{ }^{\circ} \mathrm{C}, 175^{\circ} \mathrm{C}\right.$ and $\left.190{ }^{\circ} \mathrm{C}\right)$ and two residence times (15 min and $1 \mathrm{~h}$ ). The chemical composition, enzymatic hydrolysis and porosity analysis were done for native wood and solid fraction obtained after LHW and SE pretreatments. The porosity analysis was performed by inverse size exclusion chromatography method. Additionally, inhibitors of hydrolysis and fermentation processes in the liquid and solid fractions obtained after pretreatments were examined. Based on the results, it was found that the tested pretreatments caused the greatest changes in the chemical content of hemicelluloses. It was found that after LHW and SE pretreatments up to $99.1 \%$ or $94.0 \%$, respectively, of hemicelluloses were removed from the obtained solid fraction. Moreover, the LHW and SE processes greatly enhanced the enzymatic digestibility of fast-growing poplar wood. The highest glucose yield was achieved after 15 min of SE pretreatment at $190{ }^{\circ} \mathrm{C}$ and was $676.4 \mathrm{mg} / \mathrm{g}$ pretreated biomass, while in the case of xylose the highest value (119.3 mg/g pretreated biomass) was obtained after 15 min of LHW pretreatment at $160{ }^{\circ} \mathrm{C}$. Generally, after SE pretreatment process, more inhibitors were formed, and a greater effect of porous structure development was noticed than after LHW pretreatment. Despite this difference, the average glucose contents and yields after enzymatic hydrolysis of pretreated biomass were generally similar regardless of the pretreatment used.
\end{abstract}

Andrzej Antczak

andrzej_antczak@sggw.edu.pl

1 Institute of Wood Sciences and Furniture, Warsaw University of Life Sciences - SGGW,

Warsaw, Poland 


\section{Introduction}

Alternative energy sources are experiencing great interest worldwide. One of them is biofuels produced from agricultural raw materials (Fay and Golomb 2002; Drapcho et al. 2008; Brethauer and Studer 2015). Currently, the most commonly used biofuels are biodiesel and bioethanol. Biodiesel is produced mainly from edible oils: rapeseed, palm, soybean or peanut. However, bioethanol is obtained mainly from sugar cane (Brazil) and maize (USA) (Drapcho et al. 2008). The most important advantages of using biofuels from renewable sources include reduction in greenhouse gas emissions, biodegradability, independence of the world economy from oil suppliers, and development of the agricultural products market. Lignocellulosic biomass is one of the raw materials for the production of high potential biofuels. It can be used as a solid biofuel (combustion) or gas biofuel (biogas - mainly biomethane), but it can also be processed to obtain liquid biofuel (e.g., bioethanol).

Wood biomass, as a renewable raw material, may become an important alternative to shrinking fossil fuel resources (crude oil, coal and natural gas). Currently, due to the intensive felling of trees, the forest area has drastically decreased, which contributes to the increase in global warming. Therefore, in the last 20 years, especially in the West, there has been a great interest in tree biotechnology. Poplars belong to species whose genome has been fully sequenced, characterized by a high and rapid biomass growth, usually from 6 to 12 t/ha.year, and for special species from $13 \mathrm{t} / \mathrm{ha}$-year to even $18 \mathrm{t} / \mathrm{ha}$ year (Labrecque and Teodorescu 2005; Sannigrahi et al. 2010). In addition, they are able to adapt to adverse environmental conditions, are a species that is suitable for plantation and can be used for phytoremediation of polluted industrial areas. Worldwide scientific research includes both the search for a new fast-growing poplar species and hybrids, as well as genetically modified lines with changed chemical composition (Dinus 2001; Kačik et al. 2012; Zamora et al. 2013; Guo et al. 2014; Stanton et al. 2019). It is worth emphasizing that tree genetic modifications, which can be developed in the future, are much more easily accepted by the public than in the case of such modifications for food plants. Poplars can be successfully planted and cultivated because the cutting takes place long before the tree reaches maturity with the capacity to produce seeds. It takes from 15 to 20 years depending on the species and the individual tree, while logging is carried out after the period of the fastest biomass growth, usually not longer than 3-7 years. Another important aspect in bioethanol production technology is the chemical composition of biomass. In this case, the young fast-growing wood (2.5-year-old to 5-year-old) of Populus trichocarpa has favorable chemical composition, because it is made of high cellulose content (52.0-53.0\%), low lignin (19.1-20.1\%) and extractives (1.2-1.7\%) content (Antczak et al. 2018a, 2019). Additionally, the young wood of $P$. trichocarpa is a rich source of simple sugars (glucose and xylose), which can be produced in acid or enzymatic hydrolysis reactions and turned into bioethanol through fermentation.

Biomass processing into bioethanol consists of several stages: raw material pretreatment, enzymatic hydrolysis, fermentation and purification of bioethanol 
(usually by distillation) (Verardi et al. 2012). Pretreatment of raw material and hydrolysis of polysaccharides are the most important stages, because the yield of ethanol obtained and the cost-effectiveness of the entire process depend on these stages. The goal of most of the research on the use of lignocellulosic biomass for the production of bioethanol is to develop a technology that will allow the comprehensive use of all lignocellulosic raw material (both cellulose and hemicelluloses, as well as lignin), which will increase the efficiency of bioethanol production. Pretreatment methods are divided into physical (milling or irradiation), physicochemical (steam explosion-SE, liquid hot water-LHW or supercritical carbon dioxide explosion), chemical (ozonolysis, acid, or alkaline hydrolysis) and biological (microbiological or enzymatic) (Taherzadeh and Karimi 2007; Kumar et al. 2009; Zheng et al. 2009; Alvira et al. 2010).

In recent years, the attention has been focused on the SE pretreatment, as it is an efficient method with low environmental impact (Langan et al. 2014; Singh et al. 2015). Additionally, the energy consumption during this process is relatively moderate (lower than in the LHW pretreatment), there is a possibility of using large biomass particles as a feedstock and the process was even developed on an industrial scale. Many studies have been carried out on this subject for different kinds of lignocellulosic material, which proves that the process is well known and documented (Brownell et al. 1986; Brownell and Saddler 1987; Nunes and Pourquie 1996; Ballesteros et al. 2006; Fang et al. 2011; Martín-Sampedro et al. 2011; Liu et al. 2013; Li et al. 2015; Pielhop et al. 2016; Simangunsong et al. 2018; Balan et al. 2020). Biomass during the steam explosion process is treated with high-pressure steam typically at a temperature of $160-260{ }^{\circ} \mathrm{C}$. Subsequently, after several seconds to a few minutes, pressure is suddenly reduced, and the biomass undergoes an explosive decompression. As a result of the steam explosion, a major part of the hemicelluloses is removed from the solid material, the lignin is transformed, and the cellulose becomes more susceptible to enzymatic hydrolysis.

The LHW method is the second process which has often been used for the pretreatment of various lignocellulosic raw materials (Wyman et al. 2005; Ragauskas et al. 2006; Hu and Ragauskas 2012; Li et al. 2014, 2017; Michelin and Teixeira 2016; Antczak et al. 2018a; Imman et al. 2018). The pretreatment is generally conducted at elevated temperatures $\left(160-240{ }^{\circ} \mathrm{C}\right.$ ) for a few minutes to an hour, under pressure, without addition of chemicals other than water. The LHW process significantly enhances enzymatic hydrolysis of the lignocellulosic biomass. During the process, the accessible and susceptible surface area of the polysaccharides increases. Moreover, nearly all of the hemicelluloses are transferred to the liquid fraction, separated from the solid fraction and the lignin structure changes. In this way, the solid and liquid fractions contain less inhibitors (than in the SE pretreatment), which could reduce enzymatic hydrolysis and yeast fermentation processes. The most important inhibitors of hydrolysis and fermentation processes formed during SE and LHW pretreatment include furfural, 5-hydroxymethylfurfural (HMF), acetic acid, levulinic acid, formic acid and lignin (Olsson and HahnHägerdal 1996; Sreenath and Jeffries 2000; Cantarella et al. 2004; Kim et al. 2011; Arora et al. 2013; Rahikainen et al. 2013; Vermaas et al. 2015; Zawadzki et al. 2015). The main directions of the formation of inhibitors were presented 
and discussed by Jönsson et al. (2013). Furfural and HMF are furan aldehydes, which are formed as a result of the dehydration reaction of pentoses and hexoses, respectively. Acetic acid is a product of the hydrolysis reaction of acetic groups of hemicelluloses. On the other hand, formic and levulinic acid are products of thermochemical degradation of polysaccharides. Formic acid is formed as a result of furfural and HMF degradation, while levulinic acid is formed as a result of HMF degradation. Still another substance with inhibitory properties, especially the enzymatic hydrolysis process, is lignin. Moreover, many phenolic compounds, which inhibit the hydrolysis and fermentation process, may be formed from lignin during pretreatment of lignocellulosic raw material. In addition, some extractives found in lignocellulosic biomass are phenolic compounds. The process of formation of the above inhibitors (their quantity and quality) largely depends on the type of biomass used, the pretreatment method and the conditions of the pretreatment used.

Another very important factor, which affects the efficiency of the hydrolysis process, is porosity. According to the literature findings, only the pores with size larger than $5 \mathrm{~nm}$ can accommodate the cellulase enzymes and start the hydrolysis process (Zhao et al. 2012). To measure the biomass porosity, different methods are used: Simons' stain, Congo red, nitrogen porosimetry or NMR (nuclear magnetic resonance) (Meng et al. 2013; Dougherty et al. 2014; Karimi and Taherzadeh 2016; Alam et al. 2019). Other methods: DSC (differential scanning calorimetry) and ISEC (inverse size exclusion chromatography) are also used, but most often for porosity analysis of silica, naphthalene, soil or hydrogels (Brun et al. 1977; Jerabek et al 1993; Guan and Guiochon 1996; Strange et al. 2003; Yao and Lenhoff 2004; Kozłowski et al. 2010; Charmas and Skubiszewska-Zięba 2017; Pfeifer et al. 2021) and pulps, nitrocellulose or thermally modified wood (Berthold and Salmén 1997; Książczak et al 2003; Fahlén and Salmén 2005; Park et al. 2006; Zauer et al. 2014; Szadkowski and Szadkowska 2020). In the available literature, there is scarce information about using ISEC method for porosity analysis of wood, especially wood of the fast-growing poplars in a context of bioethanol production. Hence, in this respect the use of the above method to study the porosity of the fast-growing poplar wood is innovative and can be interesting. The pore size of biomass, can be increased by pretreatment processes like LHW or SE. In these processes, mainly the removal of hemicelluloses causes the increase in average pore size. Similarly, the removal of lignin gives the same effect.

The aim of the study was to compare the effectiveness of the two most commonly used physicochemical pretreatment methods (LHW and SE) of fast-growing poplar wood (Populus trichocarpa). Such a comparison is innovative and also very interesting, as the available literature lacks this type of research carried out on one material, in particular fast-growing poplar species. The chemical composition, enzymatic hydrolysis efficiency and biomass porosity were studied in this work. The porosity of the fast-growing poplar wood was analyzed by ISEC method. In addition, the presence of inhibitors in the liquid and solid fractions obtained after pretreatments was examined. The authors decided to verify two hypotheses: (1) LHW and SE are effective pretreatment methods and greatly enhance the enzymatic digestibility of fast-growing poplar wood; (2) ISEC method is a good tool for porosity analysis 
of native fast-growing poplar wood and solid fraction obtained after LHW and SE pretreatments.

\section{Materials and methods}

\section{Materials}

In this study, debarked wood of 5-year-old fast-growing poplar (Populus trichocarpa Torr. and A. Gray ex Hook) was used. The material was obtained from the experimental field at Wolica, Institute of Biology, Department of Genetics, Plant Breeding and Biotechnology at Warsaw University of Life Sciences.

At the beginning, the wood was finely ground into the form of sawdust. In this study, the fraction between 0.43 and $1.02 \mathrm{~mm}$ was used. This fraction was pretreated using LHW and SE processes. After that, the feedstock was subjected to enzymatic hydrolysis. All of the chemical substances were of analytical grade and purchased from Chempur (Piekary Śląskie, Poland) and Sigma-Aldrich (Taufkirchen, Germany).

\section{Methods}

\section{LHW and SE pretreatment processes}

The LHW and SE pretreatment processes were done in a stainless-steel reactor with a volume of $250 \mathrm{~mL}$. At the beginning, the air-dried feedstock (about $20 \mathrm{~g}$ ) was placed in a $400 \mathrm{~mL}$ beaker and saturated with $220 \mathrm{~mL}$ of distilled water using a magnetic stirrer at $90{ }^{\circ} \mathrm{C}$ for $20 \mathrm{~min}$. This treatment causes a swelling of the wood and facilitates the pretreatment process. Next, the beaker content was quantitatively transferred to the reactor and supplemented with distilled water to a volume of $250 \mathrm{~mL}$. The proportion of the wood to distilled water was 1:12.5. The LHW and SE pretreatment processes were conducted at three different temperatures: $160{ }^{\circ} \mathrm{C}$, $175^{\circ} \mathrm{C}$ and $190{ }^{\circ} \mathrm{C}$. Two different residence times (15 min and $1 \mathrm{~h}$ ) of the wood in the reactor were used at each temperature.

Finally, after reaching the set parameters (temperature and time), to stop the LHW pretreatment process, the reactor was cooled in a bath filled with ice and sodium chloride. The next day, the solid fraction was separated from the liquid fraction using a Büchner funnel. The solid fraction was washed with distilled water until the $\mathrm{pH}$ between 5 and 6 was achieved. The washed solid fraction was placed in a sealed polyethylene bag and stored in the refrigerator at $6{ }^{\circ} \mathrm{C}$. In turn, the liquid fraction was placed in a volumetric flask, supplemented with distilled water to a volume of $1 \mathrm{~L}$ and also stored in the refrigerator at $6{ }^{\circ} \mathrm{C}$. Two experiments were performed for each LHW pretreatment under given temperature and time conditions.

In case of the SE pretreatment process, after reaching the set parameters (temperature and time), the pneumatic drain valve was opened to bring about sudden decompression in the system. Afterward, the solid and liquid fractions were transferred 
from the receiver to a Büchner funnel to separate them. The unwashed solid fraction was placed in a sealed polyethylene bag and stored in the refrigerator at $6{ }^{\circ} \mathrm{C}$. In turn, the liquid fraction was placed in a measuring cylinder, supplemented with distilled water to a volume of $3.8 \mathrm{~L}$ and also stored in the refrigerator at $6{ }^{\circ} \mathrm{C}$. Two experiments were performed for each SE pretreatment under given temperature and time conditions.

\section{Chemical composition analysis}

The chemical composition analysis was determined for native wood and solid fraction obtained after LHW and SE pretreatments. At the beginning, the material was dried at $105{ }^{\circ} \mathrm{C}$ until the constant weight was achieved. Afterward, the material was extracted in a Soxhlet apparatus according to the procedure by Sluiter et al. (2008) using a mixture of chloroform and $96 \%$ ethanol $(93: 7 \mathrm{w} / \mathrm{w})$ for $15 \mathrm{~h}$. This mixture is a very good solvent of polar and nonpolar low molecular substances present in poplar wood, such as tannins, sterols or fatty acids. Antczak et al. (2006) found that azeotropic chloroform-ethanol mixture can be used as a substitute for the previously used mixture of benzene and ethanol. A small part of the extract was collected for gas chromatography-mass spectrometry (GC-MS) analysis to identify inhibitors. The extracted material was used for chemical composition analysis. The following analyses were done:

- acid insoluble lignin (Klason lignin) content determination according to TAPPI T222 om-02 (2006);

- acid soluble lignin content determination by spectrophotometric method according to TAPPI UM 250 (1985);

- cellulose content determination by Kürschner-Hoffer method (Saeman et al. 1954; Krutul 2002);

- holocellulose content determination by sodium chlorite method (Wise et al. 1946);

- hemicelluloses content determination, calculated as the difference between the holocellulose and cellulose contents.

\section{Enzymatic hydrolysis and HPLC sugars analysis}

The enzymatic hydrolysis was carried out on native wood and solid fraction obtained after LHW and SE pretreatments. In this process, the Cellic CTec2 enzyme (Novozymes, Bagsvaerd, Denmark) was used. The activity of enzyme was 148 FPU/mL. Whatman no.1 filter paper was used to measure the enzyme activity by the NREL method (Adney and Baker 1996). The enzymatic hydrolysis was done according to the procedure described by Antczak et al. (2018a). The cellulose concentration was $1 \% \mathrm{w} / \mathrm{w}$. The enzymatic hydrolysis process was carried out in sealed screwcapped test tubes and the total volume of the mixture was $10 \mathrm{~mL}$. After $72 \mathrm{~h}$ of the enzymatic hydrolysis process, the contents of glucose and xylose in the supernatant were determined by high-performance liquid chromatography (HPLC). The HPLC system (LC-20AD, Shimadzu, Kyoto, Japan) was equipped with refractometric 
detector (RID-10A, Shimadzu, Kyoto, Japan). The HPLC sugars analysis was done using RHM-Monosaccharide column (300 mm $\times 7.80 \mathrm{~mm}$, Rezex, Torrance, USA) at $80{ }^{\circ} \mathrm{C}$ and redistilled water as a mobile phase flowing with $0.6 \mathrm{~mL} / \mathrm{min}$. All of the enzymatic hydrolysis tests were done in triplicate and single standard deviations were calculated.

\section{Analysis of released sugars and inhibitors}

The contents and yields of released sugars (cellobiose, glucose and xylose), furan aldehydes (furfural and 5-hydroxymethylfurfural) and organic acids (formic, acetic and levulinic) in liquid fractions obtained after LHW and SE pretreatments were analyzed using HPLC system under the same conditions as was earlier presented.

Furthermore, the qualitative analysis of lignin derived phenolic compounds was done using GC-MS technique. In this analysis, chloroform-96\% ethanol $(93: 7)_{\mathrm{w} / \mathrm{w}}$ extracts of solid fraction obtained after LHW and SE pretreatments were used. The analysis of phenolic compounds was carried out on the gas chromatograph (GC-2010, Shimadzu, Kyoto, Japan) connected to the mass spectrometer (GCMS-QP2010, Shimadzu, Kyoto, Japan). In the analysis, a Zebron ZB-5 ms $(30 \mathrm{~m} \times 0.25 \mathrm{~mm} \times 0.25 \mu \mathrm{m})$ capillary column (Phenomenex, Torrance, CA, USA) was used. Samples were introduced to the column with the AOC-20i autosampler. To support the work of the chromatograph and for data collection, GCMSsolution Version 2.72 software was used. The individual peaks were identified by comparing the spectrometric spectrum with spectral libraries NIST11 and NIST11b. The results with a correlation of less than $80 \%$ were not considered when identifying compounds in the NIST libraries. Each series of samples was analyzed on the data for the current tuning, made immediately before analysis. In GC-MS analysis, the following program was used: temperature $50{ }^{\circ} \mathrm{C}$ maintained for $7 \mathrm{~min}$, increase of $10{ }^{\circ} \mathrm{C} / \mathrm{min}$ to $320{ }^{\circ} \mathrm{C}$ maintained for $12 \mathrm{~min}$; flow $0.8 \mathrm{~mL} / \mathrm{min}$; the temperature of the injection $250{ }^{\circ} \mathrm{C}$; the detector voltage $1.1 \mathrm{kV}$; carrier gas helium 5.0. All of the released sugars and inhibitors analyses were done in duplicate or triplicate and single standard deviations were calculated.

\section{Porosity analysis}

The porosity analysis of native wood and solid fraction obtained after LHW and SE pretreatments was done by ISEC method. Porosity determination was carried out using HPLC system (LC-20AD, Shimadzu, Kyoto, Japan). The HPLC system was equipped with an oven (CTO-10A, Shimadzu, Kyoto, Japan) with space for two $20 \mu \mathrm{L}$ dosing loops and two columns, two pumps (LC-20AD, Shimadzu, Kyoto, Japan), degasser (DGU-20A, Shimadzu, Kyoto, Japan), refractometric detector (RID-10A, Shimadzu, Kyoto, Japan) and controller (CBM-10A, Shimadzu, Kyoto, Japan). In the ISEC method, to determine the distribution of pores available in the analyzed material, the following standards were used: dextrans (1080-401,300 Da, Fluka-Honeywell, North Carolina, USA), polyethylene glycols (62-430 Da, SigmaAldrich, Taufkirchen, Germany), maltose (342 Da, Chempur, Piekary Śląskie, Poland), glucose (180 Da, Chempur, Piekary Śląskie, Poland) and methanol (32 Da, 
Chempur, Piekary Śląskie, Poland). The porosity analysis by ISEC method was based on earlier studies (Szadkowski et al. 2015; Radomski 2015; Zawadzki et al. 2016). In the ISEC method, blank stainless-steel columns (250 mm $\times 4.0 \mathrm{~mm}$, Macherey-Nagel, Dueren, Germany) were filled with native poplar wood and pretreated solid fraction obtained after LHW and SE. The lignocellulosic material tested was in a moist state. The columns on both sides were equipped with metal filters (1/4", $4.6 \mathrm{~mm} 5 \mu \mathrm{m}$, Macherey-Nagel, Dueren, Germany) in order to prevent the detector damage by fine particles of lignocellulosic material. In this way, prepared columns were used for chromatographic analysis of above standards, which were dissolved in redistilled water. The conditions of ISEC analysis were as follows: $35^{\circ} \mathrm{C}$ and redistilled water as a mobile phase. Prior to the ISEC analysis, the columns filled with wood material were stabilized in the flow of mobile phase. The initial flow was $0.02 \mathrm{~mL} / \mathrm{min}$ for $12 \mathrm{~h}$, and then the flow was increased by $0.02 \mathrm{~mL} / \mathrm{min}$ for every $0.5 \mathrm{~h}$. When the flow rate reached $0.5 \mathrm{~mL} / \mathrm{min}$, the refractometric detector was activated. The ISEC method was started from standard analysis, which had the highest molar masses $(401,300-66,700 \mathrm{Da})$ at a flow rate of $0.5 \mathrm{~mL} / \mathrm{min}$. For standards $(43,500-4440 \mathrm{Da})$, the eluent flow was $0.7 \mathrm{~mL} / \mathrm{min}$ and for standards with a low molar mass (below $4440 \mathrm{Da}$ ), the mobile phase was $1.0 \mathrm{~mL} / \mathrm{min}$. The change of the mobile phase flow was associated with an improvement in the separation of the standards according to size during analysis.

\section{Results and discussion}

\section{Chemical composition analysis}

The chemical composition analysis was determined for native Populus trichocarpa wood and solid fraction obtained after LHW and SE pretreatments. The results are presented in Tables 1 and 2.

Based on the results presented in Tables 1 and 2, it was observed that LHW and SE pretreatments caused major changes in the chemical composition of the tested materials. The greatest changes were noticed in the hemicelluloses content. The hemicelluloses content decreased from 33.4 to $0.3 \%$ and $2.0 \%$, with increasing temperature and time of LHW and SE pretreatments. On the other hand, a large increase (from 1.5 to $17.0 \%$ ) in extractives content was observed. Analogical relationships were obtained by other researchers, who tested different biomass, like poplar wood (Li et al. 2017; Antczak et al. 2018a, b), pine wood (Negro et al. 2003), eucalyptus wood (Martín-Sampedro et al. 2011) or corn stover (Li et al. 2014; Lu et al. 2016; Akus-Szylberg et al. 2018) using above pretreatment methods. The increasing contents of soluble low molecular substances are certainly products of the breakdown of structural substances such as cellulose, lignin and, above all, hemicelluloses. Some volatile substances were identified by the GC-MS analysis. The GC-MS analysis confirmed the presence of vanillin and syringaldehyde in the chloroform-ethanol extract, which are known products of lignin decomposition during biomass pretreatment (Jönsson and Martín 2016; Brethauer et al. 2020). The results of GC-MS analysis are presented in Table 3 and discussed later in this paper. 
Table 1 Chemical composition of native P. trichocarpa wood and washed solid fraction obtained from the $P$. trichocarpa wood after the LHW pretreatment

\begin{tabular}{|c|c|c|c|c|c|c|c|}
\hline \multirow{4}{*}{$\begin{array}{l}\text { Chemical compo- } \\
\text { sition }(\%)\end{array}$} & \multicolumn{7}{|c|}{ Populus trichocarpa } \\
\hline & \multirow[t]{3}{*}{ Native wood } & \multicolumn{6}{|c|}{ Solid fraction after LHW pretreatment } \\
\hline & & \multicolumn{2}{|l|}{$160^{\circ} \mathrm{C}$} & \multicolumn{2}{|l|}{$175^{\circ} \mathrm{C}$} & \multicolumn{2}{|l|}{$190^{\circ} \mathrm{C}$} \\
\hline & & $15 \mathrm{~min}$ & $1 \mathrm{~h}$ & $15 \mathrm{~min}$ & $1 \mathrm{~h}$ & $15 \mathrm{~min}$ & $1 \mathrm{~h}$ \\
\hline $\begin{array}{l}\text { Extractives } \\
\text { (mixture of chlo- } \\
\text { roform and 96\% } \\
\text { ethanol (93:7 } \\
\text { w/w) }\end{array}$ & $1.5 \pm 0.3$ & $6.5 \pm 0.1$ & $8.2 \pm 0.0$ & $11.7 \pm 0.0$ & $12.9 \pm 0.1$ & $15.6 \pm 0.1$ & $16.6 \pm 0.1$ \\
\hline $\begin{array}{l}\text { Acid insoluble } \\
\text { lignin (Klason } \\
\text { lignin) }\end{array}$ & $18.4 \pm 0.1$ & $18.3 \pm 0.1$ & $19.0 \pm 0.3$ & $18.2 \pm 0.1$ & $18.7 \pm 0.2$ & $18.7 \pm 0.4$ & $19.3 \pm 0.3$ \\
\hline $\begin{array}{l}\text { Acid soluble lignin } \\
\text { (spectrophoto- } \\
\text { metric method) }\end{array}$ & $2.4 \pm 0.1$ & $0.3 \pm 0.1$ & $0.8 \pm 0.0$ & $0.6 \pm 0.1$ & $0.3 \pm 0.0$ & $0.5 \pm 0.1$ & $0.4 \pm 0.0$ \\
\hline $\begin{array}{l}\text { Cellulose }^{\mathrm{a}} \text { (Kür- } \\
\text { schner-Hoffer } \\
\text { method) }\end{array}$ & $53.0 \pm 0.2$ & $68.8 \pm 0.4$ & $72.8 \pm 0.5$ & $73.7 \pm 0.3$ & $75.2 \pm 0.1$ & $77.8 \pm 0.5$ & $79.7 \pm 0.4$ \\
\hline $\begin{array}{l}\text { Holocellulose }^{\mathrm{a}} \\
\text { (sodium chlorite } \\
\text { method) }\end{array}$ & $86.4 \pm 0.5$ & $75.1 \pm 0.4$ & $76.9 \pm 0.3$ & $76.7 \pm 0.5$ & $77.7 \pm 0.4$ & $79.6 \pm 0.4$ & $80.0 \pm 0.3$ \\
\hline $\begin{array}{l}\text { Hemicelluloses }^{\mathrm{a}} \\
\text { (calculated as } \\
\text { the difference } \\
\text { between the } \\
\text { holocellulose } \\
\text { and cellulose } \\
\text { contents) }\end{array}$ & 33.4 & 6.3 & 4.1 & 3.0 & 2.5 & 1.8 & 0.3 \\
\hline
\end{tabular}

${ }^{a}$ Results should be treated only in an approximate and comparative way, as the methods used did not allow for completely pure substances to be obtained; the errors $( \pm)$ refer to standard deviations - at least three replications were done to obtain the average

In the case of cellulose and lignin, minor changes were observed. The cellulose content apparently increased with increasing temperature and time of pretreatment. The apparent increase was due to the drastic loss of hemicelluloses, whereas the Klason lignin content remained almost constant at about 18-19\%. Only in the case of SE pretreatment at $190{ }^{\circ} \mathrm{C}(15 \mathrm{~min}$ and $1 \mathrm{~h})$, a few percent (about 2\%) reduction in Klason lignin content was noticed. Similarly, the acid soluble lignin was more prone to the degrading effects of pretreatment, the contents of which decreased from $2.4 \%$ to as much as $0.3 \%$. Other researchers also did not observe a large effect of LHW and SE pretreatments on the removal of lignin from biomass (Martín-Sampedro et al. 2011; Ko et al. 2015; Li et al. 2017; Antczak et al. 2018b). However, a slight loss of lignin content may be caused by its softening under the influence of heat and slow depolymerization causing dissolution of its small fragments (Excoffier et al. 1991). 
Table 2 Chemical composition of native $P$. trichocarpa wood and unwashed solid fraction obtained from the $P$. trichocarpa wood after the SE pretreatment

\begin{tabular}{|c|c|c|c|c|c|c|c|}
\hline \multirow{4}{*}{$\begin{array}{l}\text { Chemical composi- } \\
\text { tion }(\%)\end{array}$} & \multicolumn{7}{|c|}{ Populus trichocarpa } \\
\hline & \multirow{3}{*}{$\begin{array}{l}\text { Native } \\
\text { wood }\end{array}$} & \multicolumn{6}{|c|}{ Solid fraction after SE pretreatment } \\
\hline & & \multicolumn{2}{|l|}{$160^{\circ} \mathrm{C}$} & \multicolumn{2}{|l|}{$175^{\circ} \mathrm{C}$} & \multicolumn{2}{|l|}{$190^{\circ} \mathrm{C}$} \\
\hline & & $15 \mathrm{~min}$ & $1 \mathrm{~h}$ & $15 \min$ & $1 \mathrm{~h}$ & $15 \min$ & $1 \mathrm{~h}$ \\
\hline $\begin{array}{l}\text { Extractives (mixture } \\
\text { of chloroform and } \\
96 \% \text { ethanol (93:7 } \\
\text { w/w) }\end{array}$ & $1.5 \pm 0.3$ & $3.4 \pm 0.1$ & $6.2 \pm 0.0$ & $7.2 \pm 0.1$ & $10.9 \pm 0.2$ & $13.7 \pm 0.0$ & $17.0 \pm 0.3$ \\
\hline $\begin{array}{l}\text { Acid insoluble lignin } \\
\text { (Klason lignin) }\end{array}$ & $18.4 \pm 0.1$ & $19.7 \pm 0.2$ & $18.6 \pm 0.0$ & $19.3 \pm 0.2$ & $18.1 \pm 0.1$ & $16.1 \pm 0.0$ & $16.1 \pm 0.1$ \\
\hline $\begin{array}{l}\text { Acid soluble lignin } \\
\text { (spectrophotometric } \\
\text { method) }\end{array}$ & $2.4 \pm 0.1$ & $1.5 \pm 0.1$ & $1.1 \pm 0.0$ & $0.9 \pm 0.3$ & $0.6 \pm 0.2$ & $0.5 \pm 0.0$ & $0.3 \pm 0.1$ \\
\hline $\begin{array}{l}\text { Cellulose }^{\mathrm{a}} \text { (Kürsch- } \\
\text { ner-Hoffer method) }\end{array}$ & $53.0 \pm 0.2$ & $64.7 \pm 0.3$ & $69.9 \pm 0.3$ & $71.7 \pm 0.2$ & $75.5 \pm 0.4$ & $76.3 \pm 0.1$ & $78.3 \pm 0.3$ \\
\hline $\begin{array}{l}\text { Holocellulose }^{\mathrm{a}} \\
\text { (sodium chlorite } \\
\text { method) }\end{array}$ & $86.4 \pm 0.5$ & $75.5 \pm 0.2$ & $75.5 \pm 0.3$ & $76.1 \pm 0.4$ & $78.2 \pm 0.4$ & $78.8 \pm 0.1$ & $80.3 \pm 0.4$ \\
\hline $\begin{array}{l}\text { Hemicelluloses }^{\mathrm{a}} \text { (cal- } \\
\text { culated as the dif- } \\
\text { ference between the } \\
\text { holocellulose and } \\
\text { cellulose contents) }\end{array}$ & 33.4 & 10.8 & 5.6 & 4.4 & 2.7 & 2.5 & 2.0 \\
\hline
\end{tabular}

${ }^{a}$ Results should be treated only in an approximate and comparative way, as the methods used did not allow for completely pure substances to be obtained; the errors $( \pm)$ refer to standard deviations-at least three replications were done to obtain the average

\section{Enzymatic hydrolysis and HPLC sugars analysis}

The enzymatic hydrolysis and HPLC analysis of released simple sugars (xylose and glucose) content and yield were done for native wood and solid fraction obtained after LHW and SE pretreatments. The results are presented in Fig. 1. Based on the results, it can be observed, that the applied pretreatments caused a large increase in the efficiency of enzymatic hydrolysis, and these findings are consistent with studies of other researchers (Li et al. 2014; Pielhop et al. 2016; Michelin and Teixeira 2016; Imman et al. 2018; Balan et al. 2020). The average glucose yield after enzymatic hydrolysis was $46.0 \mathrm{mg} / \mathrm{g}$ native biomass, whereas the average xylose yield was $23.1 \mathrm{mg} / \mathrm{g}$ native biomass. After LHW and SE pretreatments, much higher sugar yields were obtained. The average glucose yield was between 387.7 and $676.4 \mathrm{mg} / \mathrm{g}$ pretreated biomass, while the average xylose yield was between 48.5 and $119.3 \mathrm{mg} / \mathrm{g}$ pretreated biomass. If we compare the results presented in Fig. 1, it can be concluded that the glucose content increased with increasing time and temperature of pretreatment. The inverse relationship occurred in the case of xylose, the 
Table 3 Phenolic compounds identified in chloroform-96\% ethanol (93:7) $)_{\mathrm{w} / \mathrm{w}}$ extracts of solid fraction obtained after LHW and SE pretreatments of the $P$. trichocarpa wood determined by GC-MS technique

\begin{tabular}{|c|c|c|c|c|c|c|}
\hline \multirow[t]{3}{*}{ Retention time of analyzed compound (min) } & \multicolumn{6}{|c|}{ Extract of solid fraction obtained after LHW pretreatment } \\
\hline & \multicolumn{2}{|l|}{$160^{\circ} \mathrm{C}$} & \multicolumn{2}{|l|}{$175^{\circ} \mathrm{C}$} & \multicolumn{2}{|l|}{$190^{\circ} \mathrm{C}$} \\
\hline & $15 \min$ & $1 \mathrm{~h}$ & $15 \min$ & $1 \mathrm{~h}$ & $15 \mathrm{~min}$ & $1 \mathrm{~h}$ \\
\hline Vanillin & - & 18.749 & - & 18.819 & 18.462 & - \\
\hline Syringaldehyde & - & 21.865 & - & - & 21.088 & 21.875 \\
\hline Isoeugenol & 19.300 & - & - & - & - & - \\
\hline Eugenol & - & 21.098 & 22.303 & 21.094 & - & - \\
\hline $\begin{array}{l}\text { 3,5-Dimetoxy-4-hydroxyphenylacetic acid (a } \\
\text { derivative of syringic acid) }\end{array}$ & - & 23.065 & - & 23.065 & - & - \\
\hline $\begin{array}{l}\text { 3-Hydroxy-4-metoxybenzaldehyde (a deriva- } \\
\text { tive of vanillin) }\end{array}$ & - & - & 18.793 & - & - & - \\
\hline Vanillic acid & - & - & 19.328 & - & - & - \\
\hline Isovanillin & - & - & - & - & - & 18.739 \\
\hline \multirow[t]{4}{*}{ Acetosyringone } & - & - & - & - & - & 23.665 \\
\hline & \multicolumn{6}{|c|}{ Extract of solid fraction obtained after SE pretreatment } \\
\hline & \multicolumn{2}{|l|}{$160^{\circ} \mathrm{C}$} & \multicolumn{2}{|l|}{$175^{\circ} \mathrm{C}$} & \multicolumn{2}{|l|}{$190^{\circ} \mathrm{C}$} \\
\hline & $15 \mathrm{~min}$ & $1 \mathrm{~h}$ & $15 \mathrm{~min}$ & $1 \mathrm{~h}$ & $15 \mathrm{~min}$ & $1 \mathrm{~h}$ \\
\hline Vanillin & - & - & - & - & - & 18.598 \\
\hline Syringaldehyde & - & 21.877 & 21.857 & - & 21.838 & 21.088 \\
\hline Isoeugenol & 19.315 & - & 19.278 & - & 19.136 & - \\
\hline Eugenol & - & - & 22.298 & 21.109 & - & - \\
\hline Coniferyl aldehyde & - & - & - & - & 22.786 & - \\
\hline Acetosyringone & - & - & - & - & 23.626 & - \\
\hline
\end{tabular}

content of which decreased with increasing time and temperature of the LHW and SE pretreatments. The highest glucose yield $(676.4 \mathrm{mg} / \mathrm{g}$ pretreated biomass) was obtained after $15 \mathrm{~min}$ of SE pretreatment at $190{ }^{\circ} \mathrm{C}$, while the highest xylose yield (119.3 $\mathrm{mg} / \mathrm{g}$ pretreated biomass) was obtained after $15 \mathrm{~min}$ of LHW pretreatment at $160{ }^{\circ} \mathrm{C}$. Generally, the sugar yields after enzymatic hydrolysis of pretreated biomass in specific conditions were similar regardless of the pretreatment used.

In an earlier publication, Antczak et al. (2018a) also studied the 5-year-old $P$. trichocarpa wood in the context of enzymatic hydrolysis. The average glucose yield after enzymatic hydrolysis of LHW pretreated wood was between 431.4 and $602.0 \mathrm{mg} / \mathrm{g}$ pretreated biomass, whereas the average xylose yield was between 20.1 and $65.4 \mathrm{mg} / \mathrm{g}$ pretreated biomass. In both cases, the previously obtained results were lower than the results presented in this paper. This is probably connected to the particle size of the wood used in the pretreatment process. Previously, a fraction below $0.43 \mathrm{~mm}$ was studied. The use of finer particle size of the material makes lignin more susceptible to condensation (Shevchenko et al. 1999; Cullis et al. 2004). 


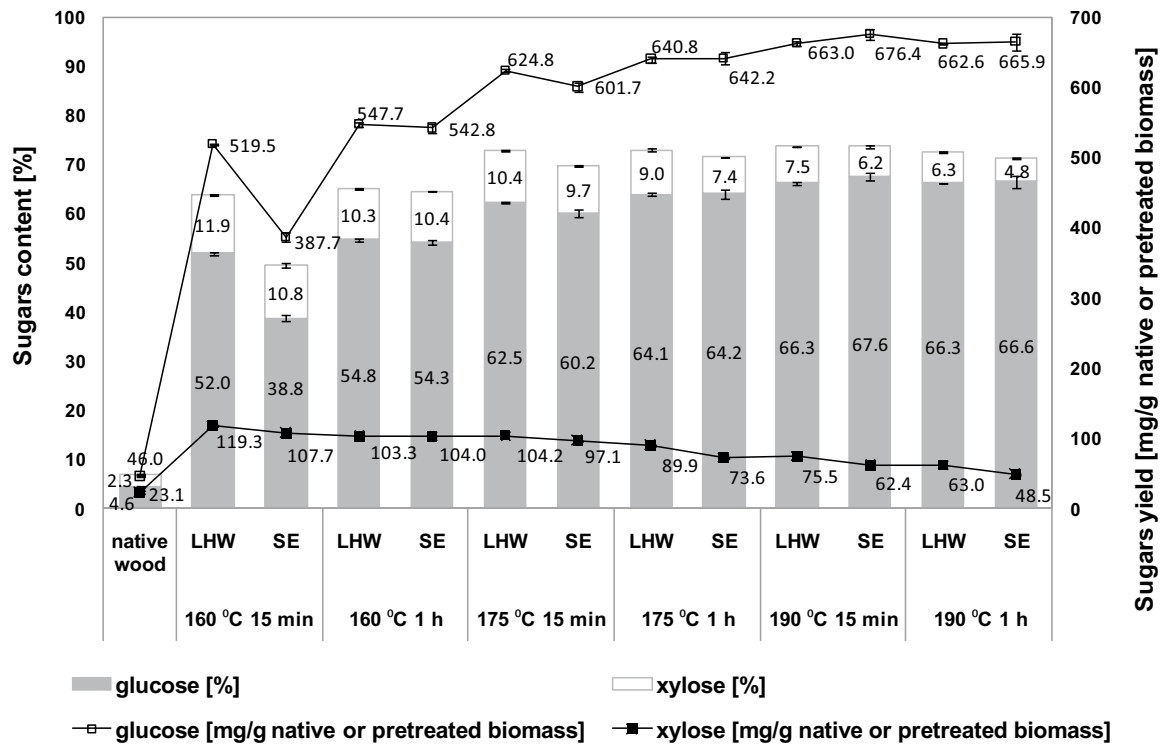

Fig. 1 Sugars content and yield after enzymatic hydrolysis of the native P. trichocarpa wood or LHW and SE pretreated P. trichocarpa wood under different conditions

The obtained results indicated that the lignin-cellulose condensation reactions occurred during the LHW pretreatment, which was earlier discussed. The condensed lignin reduces the rate and yield of enzymatic hydrolysis reaction as it impedes the accessibility of the enzymes to the cellulose, decreases the swelling of the substrate and inactivates the enzymes (enzymes can irreversibly bind to the lignin). In another publication, Akus-Szylberg et al. (2020a) studied the 7-year-old P. trichocarpa wood, which was used in the LHW pretreatment process. The pretreatment process enhanced the efficiency of enzymatic hydrolysis, but the resulting simple sugar contents were lower than in this paper and ranged for glucose from 44.6 to $47.1 \%$ and for xylose from 2.5 to $6.3 \%$.

\section{Analysis of released sugars and inhibitors}

The analysis of released sugars and inhibitors content or yield in liquid fraction obtained after LHW and SE pretreatments by HPLC method was performed. The results are presented in Figs. 2 and 3.

Based on the results shown in Fig. 2 it was found that the sum of released sugars increased with increasing temperature and time of pretreatment. The highest value of total sugar content $(7.6 \%$ and $15.0 \%)$ was achieved after $1 \mathrm{~h}$ of LHW and SE pretreatments at $175{ }^{\circ} \mathrm{C}$, whereas LHW and SE pretreatments at $190{ }^{\circ} \mathrm{C}(15 \mathrm{~min}$ and $1 \mathrm{~h}$ ) caused a gradual decrease in total released sugars content. Under these severe conditions $\left(190{ }^{\circ} \mathrm{C}, 15 \mathrm{~min}\right.$ and $1 \mathrm{~h}$ ), an intensive formation of inhibitors from released sugars took place, as presented in Fig. 3. Similar relationship was obtained 
in studies by Akus-Szylberg et al. (2020a). In this work, after LHW pretreatment of 7-year-old $P$. trichocarpa wood at $205{ }^{\circ} \mathrm{C}$ (20 min of residence time), a drastic decrease in total released sugars content was observed (from $6.5 \%$ at $190{ }^{\circ} \mathrm{C}$ to $2.8 \%$ at $205{ }^{\circ} \mathrm{C}$ ). Moreover, based on the results presented in Fig. 2, it was found that xylose was the main simple sugar in the liquid fraction obtained after the pretreatments (LHW and SE). Its yield ranged from 12.8 to $128.3 \mathrm{mg} / \mathrm{g}$ native biomass. In turn, the glucose content ranged from 3.7 to $23.2 \mathrm{mg} / \mathrm{g}$ native biomass and cellobiose from 2.1 to $9.8 \mathrm{mg} / \mathrm{g}$ native biomass. According to the results obtained by Brethauer et al. (2020), the xylose also was a dominant sugar released to a liquid fraction. As a result of SE pretreatment, the maximal yield of $30 \mathrm{mg} / \mathrm{g}$ beech wood was reached at $180{ }^{\circ} \mathrm{C}$.

The results presented in Fig. 3 proved that after SE pretreatment process more inhibitors were formed than after LHW pretreatment. The sum of inhibitors after steam explosion process was between 5.5 and $28.2 \%$, while after liquid hot water pretreatment it was between 4.0 and $14.6 \%$ only. Among the inhibitors of hydrolysis and fermentation processes, the following was analyzed: formic acid, furfural, HMF, acetic and levulinic acids. The formic acid yield in liquid fraction was generally high and ranged from 14.3 to $64.8 \mathrm{mg} / \mathrm{g}$ native biomass. The furfural yield was between 1.0 and $84.8 \mathrm{mg} / \mathrm{g}$ native biomass and the acetic and levulinic acid yield was also high and ranged from 16.5 to $132.7 \mathrm{mg} / \mathrm{g}$ native biomass. In turn, the yield of 5-hydroxymethylfurfural in liquid fraction obtained after LHW and SE pretreatments was relatively low and ranged from 0.3 to $18.6 \mathrm{mg} / \mathrm{g}$ native biomass.

Brethauer et al. (2020) obtained even lower amounts of inhibitors in a study on steam explosion pretreatment of beech wood. The yield of formic acid formed during SE pretreatment in the range from 160 to $200{ }^{\circ} \mathrm{C}$ was low and did not exceed $5.6 \mathrm{mg} / \mathrm{g}$ beech wood. In case of furfural, the maximal yield $(9.2 \mathrm{mg} / \mathrm{g}$ beech wood) was detected at $200{ }^{\circ} \mathrm{C}$ of SE pretreatment, while for HMF the maximal yield was $8.3 \mathrm{mg} / \mathrm{g}$ beech wood in a $230{ }^{\circ} \mathrm{C}$ steam explosion pretreatment. The main conclusion, which can be made is that the total inhibitors content increased with increasing temperature and pretreatment time. The lowest total inhibitors content $(4.0 \%)$ was formed at $160{ }^{\circ} \mathrm{C}$ (15 min of LHW pretreatment), while the highest $(28.2 \%)$ at $190{ }^{\circ} \mathrm{C}$ ( $1 \mathrm{~h}$ of SE pretreatment). Analogical relationships were observed in previous studies, in which 7-year-old P. trichocarpa wood was used (Akus-Szylberg et al. 2020a). In Akus-Szylberg et al. (2020a) studies, LHW pretreatment with 20 min of residence time was examined. As a result of the pretreatment, a rapid increase in the total inhibitors content (from $1.3 \%$ at $160{ }^{\circ} \mathrm{C}$ to $13.4 \%$ at $205{ }^{\circ} \mathrm{C}$ ) was observed.

The GC-MS analysis of chloroform-ethanol extracts of solid fraction obtained after LHW and SE pretreatments was done. The results are presented in Table 3. The identified compounds were mainly from degradation of lignin. Unfortunately, these compounds may be inhibitors of both hydrolysis and fermentation of sugars toward bioethanol. Based on the obtained results it was observed that the number of inhibitors was greater in samples subjected to longer pretreatment or a higher temperature than in the first, the mildest variant $\left(160{ }^{\circ} \mathrm{C}\right.$, $15 \mathrm{~min}$ ). This was assessed as a negative effect of the applied pretreatments. The identified lignin derived phenolic compounds were vanillin, syringaldehyde, 


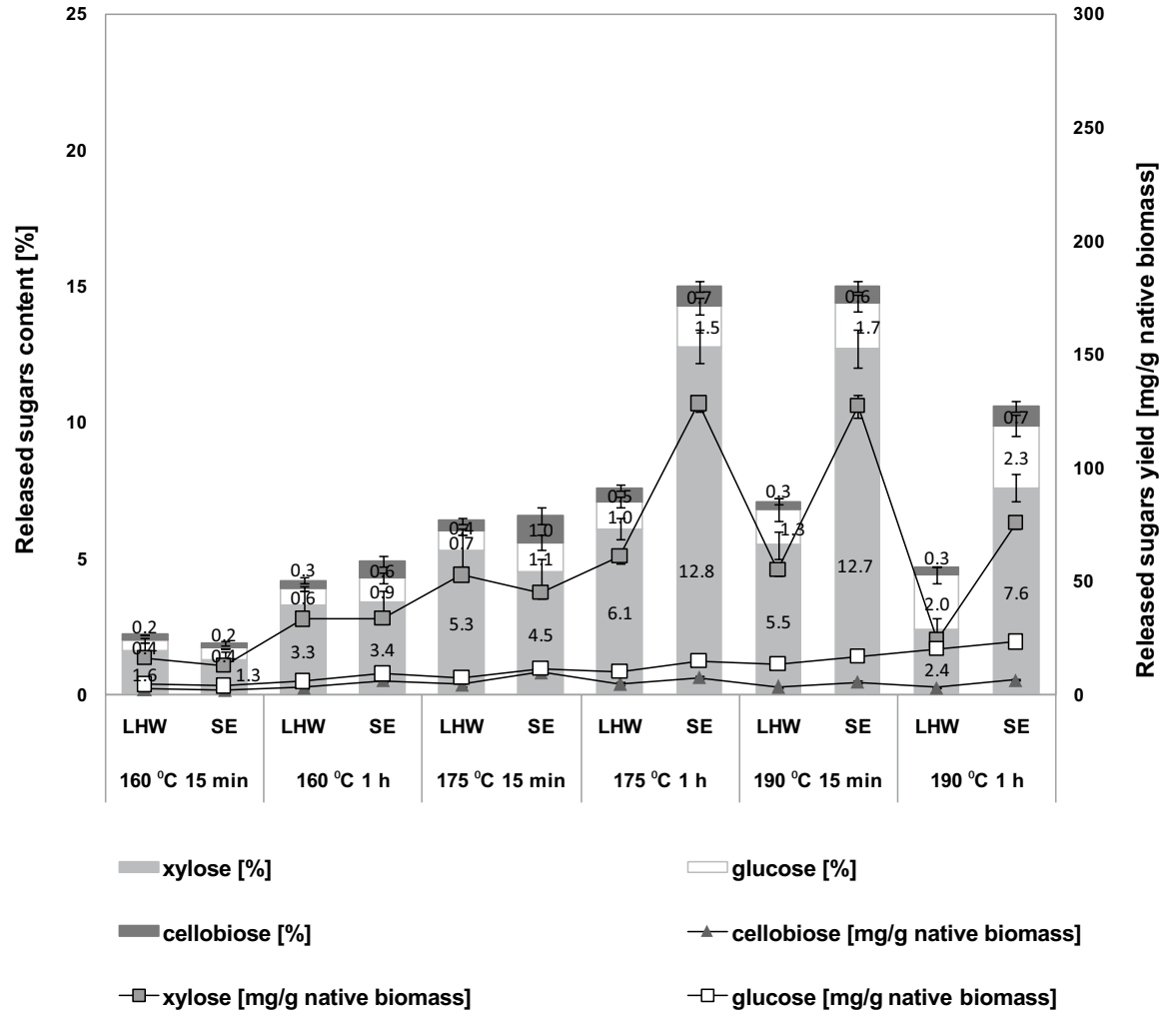

Fig. 2 Released sugars content and yield in liquid fraction obtained after LHW and SE pretreatments of the $P$. trichocarpa wood determined by HPLC technique

coniferyl aldehyde or eugenol. Vanillin and its derivatives are well-known inhibitors (Luo et al. 2002). Vanillin was identified in extracts after $1 \mathrm{~h}$ of LHW at $160{ }^{\circ} \mathrm{C}$ and $175^{\circ} \mathrm{C}$, after $15 \mathrm{~min}$ of LHW at $190{ }^{\circ} \mathrm{C}$ and also in samples after $1 \mathrm{~h}$ of SE at $190{ }^{\circ} \mathrm{C}$. Three vanillin derivatives were identified in the extract samples. The first one-isovanillin was identified in extracts after $1 \mathrm{~h}$ of $\mathrm{LHW}$ at $190{ }^{\circ} \mathrm{C}$, the second one-3-hydroxy-4-metoxybenzaldehyde in extracts after $15 \mathrm{~min}$ of LHW pretreatment at $175{ }^{\circ} \mathrm{C}$, and the last one-vanillic acid was found in extracts after 15 min of LHW at $175^{\circ} \mathrm{C}$, considered as a potential inhibitor of bioethanol fermentation (Luo et al. 2002; Zaldivar and Ingram 1999). Syringaldehyde is also considered as potential inhibitor of hydrolysis and fermentation processes. It was found in all samples after LHW and SE pretreatments at $190{ }^{\circ} \mathrm{C}$, after $15 \mathrm{~min}$ of SE at $175{ }^{\circ} \mathrm{C}$ and after $1 \mathrm{~h}$ of LHW or SE at $160{ }^{\circ} \mathrm{C}$. In a work by Cantarella et al. (2004), no effect on enzymes was observed at a concentration of $0.5 \mathrm{~g} /$ mol, but in another publication it was reported as an inhibitor (Liu and Blaschek 2010). The derivative of syringaldehyde, such as syringic acid was not found in the tested samples, but the derivative 3,5-dimetoxy-4-hydroxyphenylacetic acid was found. It was identified in extracts after $1 \mathrm{~h}$ of $\mathrm{LHW}$ at $160{ }^{\circ} \mathrm{C}$ and $175^{\circ} \mathrm{C}$. 


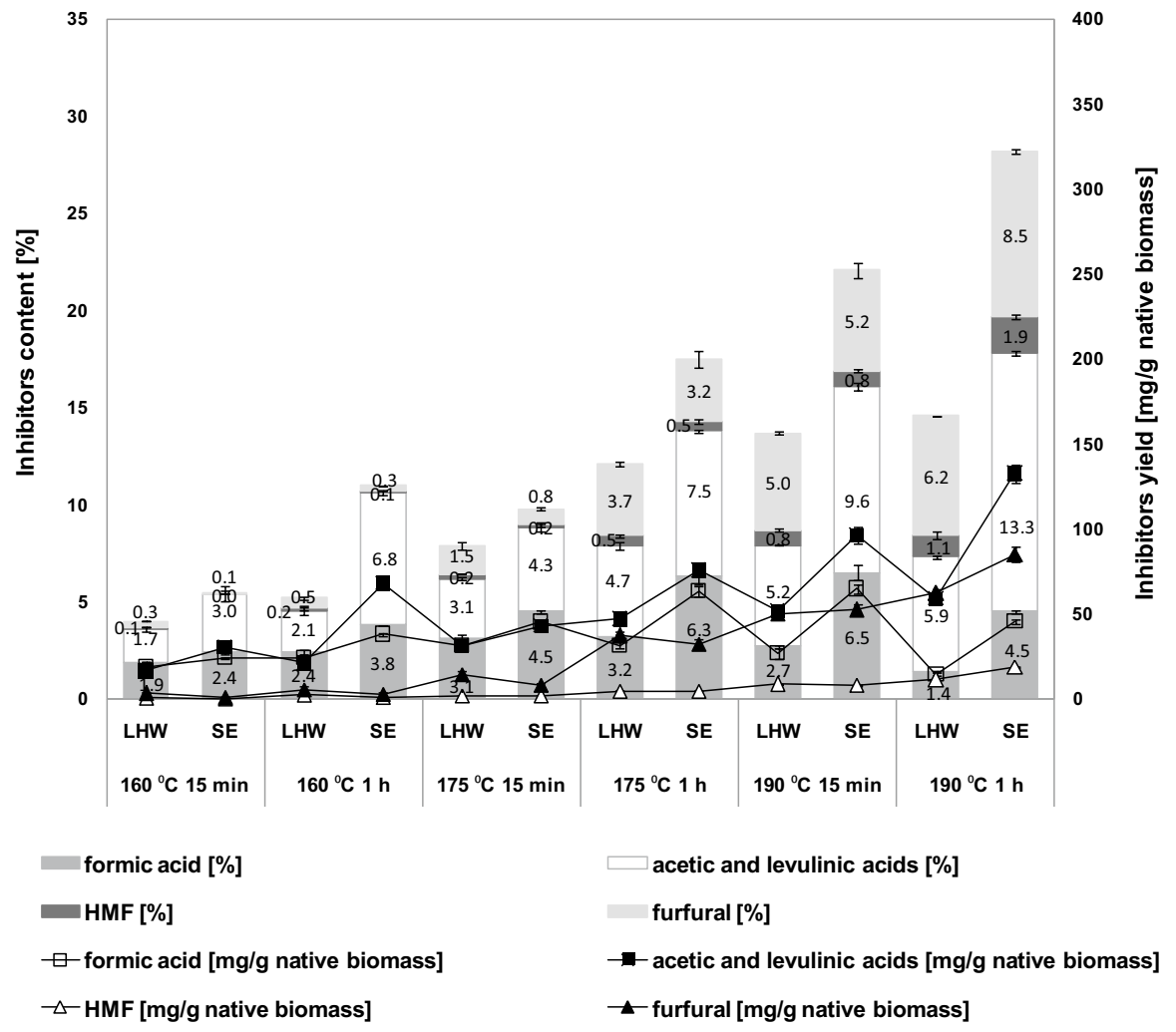

Fig. 3 Inhibitors content and yield in liquid fraction obtained after LHW and SE pretreatments of the $P$. trichocarpa wood determined by HPLC technique

The acetosyringone was found in extracts after $1 \mathrm{~h}$ of LHW and 15 min of SE pretreatments at $190{ }^{\circ} \mathrm{C}$. The coniferyl aldehyde was also found in extracts after 15 min of SE pretreatments at $190{ }^{\circ} \mathrm{C}$, whereas eugenol was identified in all samples after LHW or SE pretreatments at $175{ }^{\circ} \mathrm{C}$ and after $1 \mathrm{~h}$ of LHW at $160{ }^{\circ} \mathrm{C}$. In turn, the isoeugenol was found in extracts after $15 \mathrm{~min}$ of SE at all tested temperatures and after $15 \mathrm{~min}$ of LHW pretreatment at $160^{\circ} \mathrm{C}$.

\section{Porosity analysis}

The ISEC results of the changes in the available specific volume of pores $\left(V_{\mathrm{p}}\right)$ in poplar wood after $15 \mathrm{~min}$ and $1 \mathrm{~h}$ of LHW or SE pretreatment processes performed at $160{ }^{\circ} \mathrm{C}, 175^{\circ} \mathrm{C}$ and $190{ }^{\circ} \mathrm{C}$ are presented in Figs. 4 and 5. Based on the results, an increase in the sum of available specific volume of pores was observed after pretreatment processes compared to the native wood. The development of biomass porosity increased with time and pretreatment temperature. Moreover, a greater effect of porous structure development was noticed for a steam explosion pretreatment than in case of liquid hot water treatment. The most significant increase in the sum of 
available specific volume of poplar wood pores was observed after 15 min and $1 \mathrm{~h}$ of SE process at $190{ }^{\circ} \mathrm{C}$ (Fig. 5). The sum of $\mathrm{V}_{\mathrm{p}}$ for native poplar wood was 1.04 $\mathrm{cm}^{3} / \mathrm{g}$, while after $15 \mathrm{~min}$ and $1 \mathrm{~h}$ of SE pretreatment at $190{ }^{\circ} \mathrm{C}$ this value increased to $2.18 \mathrm{~cm}^{3} / \mathrm{g}$ and $2.09 \mathrm{~cm}^{3} / \mathrm{g}$, respectively.

An important issue in the bioethanol production process, related to the porosity of the biomass, is that only the pores with a size larger than $5 \mathrm{~nm}$ can accommodate the cellulase enzymes and start the hydrolysis process (Zhao et al. 2012). Grous et al. (1986) obtained a very high efficiency of enzymatic hydrolysis (more than $90 \%$ ) after steam explosion pretreatment, while this efficiency without pretreatment was only about $15 \%$. The porosity analysis showed a considerable increase in available volume of pores especially with sizes of 5-9 $\mathrm{nm}$. According to the ISEC results obtained in this paper, for the pore size above $5 \mathrm{~nm}$, a gradual increase in available specific volume was observed with increasing pretreatment time and temperature (Figs. 4, 5). Larger changes of available specific volume of pores for this range were observed for steam explosion pretreatment than for liquid hot water pretreatment. After $15 \mathrm{~min}$ and $1 \mathrm{~h}$ of SE process at $190{ }^{\circ} \mathrm{C}$, the $V_{\mathrm{p}}$ of pretreated biomass was $0.23 \mathrm{~cm}^{3} / \mathrm{g}$ and $0.27 \mathrm{~cm}^{3} / \mathrm{g}$, respectively, so it was over four and five times higher than for native wood $\left(0.05 \mathrm{~cm}^{3} / \mathrm{g}\right)$. Szadkowski and Szadkowska (2020) also studied porosity by ISEC method and observed an increase in available specific volume of pulps obtained by Kraft method from the wood of 2.5-year-old fast-growing poplar species. The sum of $V_{\mathrm{p}}$ for poplar pulps ranged from about $1.7 \mathrm{~cm}^{3} / \mathrm{g}$ to about $2.9 \mathrm{~cm}^{3} / \mathrm{g}$, whereas the $V_{\mathrm{p}}$ for the pores with a size larger than $5 \mathrm{~nm}$ was from about $0.2 \mathrm{~cm}^{3} / \mathrm{g}$ to about $0.9 \mathrm{~cm}^{3} / \mathrm{g}$. Unfortunately, the differences in the porosity of the pretreated biomass shown did not translate into the glucose content obtained as a result of enzymatic hydrolysis. The glucose content after enzymatic hydrolysis of pretreated biomass in specific conditions was generally similar regardless of the pretreatment used (Fig. 1). Analogical observations about the not so strong impact of porous structure development on hydrolysis efficiency were also made by other researchers (Ishizawa et al. 2007; Akus-Szylberg et al. 2020b). Akus-Szylberg et al. (2020b) studied porosity of 7-year-old Populus trichocarpa wood subjected to LHW pretreatment process. The available specific volume for the pores with a size larger than $5 \mathrm{~nm}$ increased after $20 \mathrm{~min}$ of LHW pretreatment process at $190{ }^{\circ} \mathrm{C}$ from 0.11
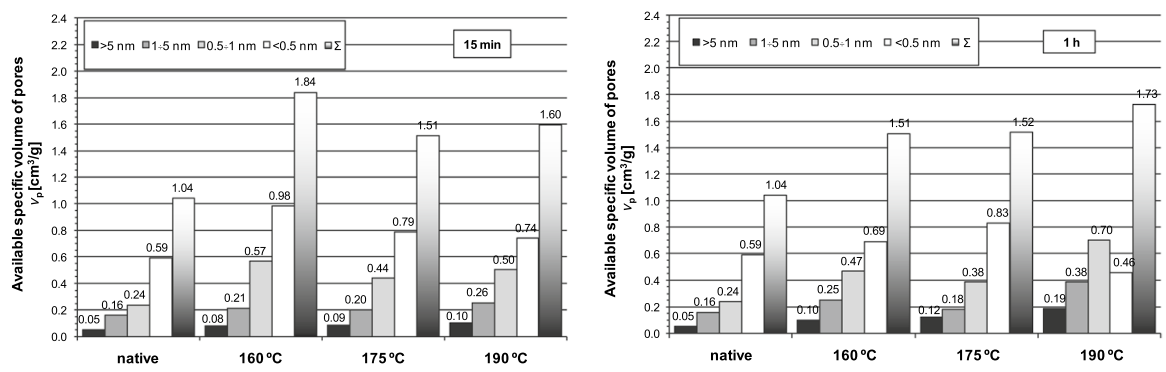

Fig. 4 Changes in the available specific volume of pores in poplar wood within the selected ranges of the standards radius after $15 \mathrm{~min}$ (figure on the left) and $1 \mathrm{~h}$ (figure on the right) of the LHW pretreatment process performed at different temperatures determined by ISEC method 

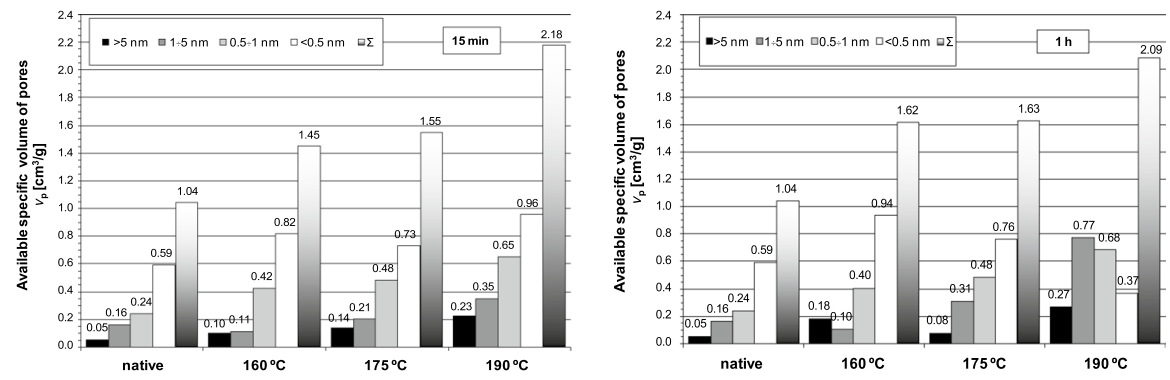

Fig. 5 Changes in the available specific volume of pores in poplar wood within the selected ranges of the standards radius after $15 \mathrm{~min}$ (figure on the left) and $1 \mathrm{~h}$ (figure on the right) of the SE pretreatment process performed at different temperatures determined by ISEC method

to $0.32 \mathrm{~cm}^{3} / \mathrm{g}$. Unfortunately, despite about a threefold increase in $V_{\mathrm{p}}$ for pretreated biomass, a significant increase in glucose content obtained after enzymatic hydrolysis was not observed. Hence, it can be concluded that the mechanism of enzymatic hydrolysis is much more complicated and requires further studies.

\section{Conclusion}

In this paper, chemical composition, enzymatic hydrolysis efficiency, inhibitors presence and porosity analysis of fast-growing poplar (Populus trichocarpa) wood after LHW and SE pretreatments were compared. Based on this study, the following conclusions were drawn:

1. LHW and SE pretreatments caused major changes in the chemical composition of tested wood. The greatest changes were observed in the hemicelluloses content. After LHW and SE pretreatments, up to $99.1 \%$ or $94.0 \%$ of hemicelluloses were removed from the obtained solid fraction.

2. The applied pretreatments (LHW and SE) greatly enhanced the enzymatic digestibility of fast-growing poplar wood. Generally, the sugar yields after enzymatic hydrolysis of pretreated biomass in specific conditions were similar regardless of the pretreatment used. The average glucose yield was up to $676.4 \mathrm{mg} / \mathrm{g}$ pretreated biomass (the highest after 15 min of SE pretreatment at $190{ }^{\circ} \mathrm{C}$ ), while the average xylose yield was up to $119.3 \mathrm{mg} / \mathrm{g}$ pretreated biomass (the highest after $15 \mathrm{~min}$ of LHW pretreatment at $160{ }^{\circ} \mathrm{C}$ ).

3. LHW and SE pretreatments of poplar wood caused polysaccharides degradation (mainly hemicelluloses) or partial decomposition of lignin. This led to formation of inhibitors of hydrolysis and fermentation processes. HPLC analysis of liquid fraction obtained after pretreatment processes proved the presence of released sugars (xylose, glucose and cellobiose) or inhibitors (furfural, HMF, formic acid, acetic acid and levulinic acid). Generally, after SE pretreatment process more inhibitors were formed than after LHW pretreatment. Additionally, GC-MS anal- 
ysis of chloroform - ethanol extracts of solid fraction obtained after LHW and SE pretreatments identified other inhibitors, which were lignin derived phenolic compounds such as vanillin, syringaldehyde, coniferyl aldehyde or eugenol.

4. The ISEC method turned out to be a good tool for porosity analysis of native fast-growing poplar wood and solid fraction obtained after LHW and SE pretreatments. The applied pretreatments caused development of poplar biomass porosity, which increased with time and pretreatment temperature. Pretreatment by steam explosion was found to have a greater effect on the development of the porous structure than treatment with liquid hot water. Despite this difference, the average glucose contents and yields after enzymatic hydrolysis of pretreated biomass were generally similar regardless of the pretreatment used.

Acknowledgements This work was financed by a research project from the National Center for Research and Development, which was "Intelligent systems for breeding and cultivation of wheat, maize, and poplar for optimized biomass production, biofuels, and modified wood" (BIOSTRATEG2/298241/10/ NCBR/2016). Poplar material used in presented work was obtained in Welcome 2008/1 project of the Foundation for Polish Science given to Prof. Stanisław Karpiński.

Author contributions The manuscript was written through contributions of all authors. All authors have given approval to the final version of the manuscript.

\section{Declarations}

Conflict of interest The article does not contain any conflict of interest.

Open Access This article is licensed under a Creative Commons Attribution 4.0 International License, which permits use, sharing, adaptation, distribution and reproduction in any medium or format, as long as you give appropriate credit to the original author(s) and the source, provide a link to the Creative Commons licence, and indicate if changes were made. The images or other third party material in this article are included in the article's Creative Commons licence, unless indicated otherwise in a credit line to the material. If material is not included in the article's Creative Commons licence and your intended use is not permitted by statutory regulation or exceeds the permitted use, you will need to obtain permission directly from the copyright holder. To view a copy of this licence, visit http://creativecommons.org/licen ses/by/4.0/.

\section{References}

Adney B, Baker J (1996) Measurement of cellulase activities (NREL/TP-510-42628). National Renewable Energy Laboratory, Golden, CO

Akus-Szylberg F, Antczak A, Bytner O, Radomski A, Krajewski K, Zawadzki J (2018) The effect of pretreatment of corn stover with liquid hot water on its chemical composition and enzymatic hydrolysis. Przem Chem 97:1866-1869. https://doi.org/10.15199/62.2018.11.10

Akus-Szylberg F, Antczak A, Zawadzki J (2020a) Hydrothermal pretreatment of poplar (Populus trichocarpa) wood and its impact on chemical composition and enzymatic hydrolysis yield. Drewno. https://doi.org/10.12841/wood.1644-3985.367.09

Akus-Szylberg F, Szadkowski J, Antczak A, Zawadzki J (2020b) Changes in poplar (Populus trichocarpa) wood porous structure after liquid hot water (LHW) pretreatment. Ann WULS-SGGW, Forestry and Wood Technology 112:71-78 
Alam A, Zhang R, Liu P, Huang J, Wang Y, Hu Z, Madadi M, Sun D, Hu R, Ragauskas AJ, Tu Y, Peng L (2019) A finalized determinant for complete lignocellulose enzymatic saccharification potential to maximize bioethanol production in bioenergy Miscanthus. Biotechnol Biofuels 12:99. https://doi. org/10.1186/s13068-019-1437-4

Alvira P, Tomás-Pejó E, Ballesteros M, Negro MJ (2010) Pretreatment technologies for an efficient bioethanol production process based on enzymatic hydrolysis: a review. Bioresour Technol 101:4851-4861. https://doi.org/10.1016/j.biortech.2009.11.093

Antczak A, Radomski A, Zawadzki J (2006) Benzene substitution in wood analysis. Ann Warsaw Agric Univ for Wood Technol 58:15-19

Antczak A, Marchwicka M, Szadkowski J, Drożdżek M, Gawron J, Radomski A, Zawadzki J (2018a) Sugars yield obtained after acid and enzymatic hydrolysis of fast-growing poplar wood species. BioResources 13:8629-8645. https://doi.org/10.15376/biores.13.4.8629-8645

Antczak A, Szadkowski J, Marchwicka M, Akus-Szylberg F, Bytner O, Zawadzki J (2018b) The study of chemical composition and enzymatic hydrolysis efficiency of poplar wood (Populus deltoides $\mathrm{x}$ maximowiczii) after steam explosion pretreatment. Ann WULS-SGGW for Wood Technol 104:139-146

Antczak A, Świerkosz R, Szeniawski M, Marchwicka M, Akus-Szylberg F, Przybysz P, Zawadzki J (2019) The comparison of acid and enzymatic hydrolysis of pulp obtained from poplar wood (Populus sp.) by the Kraft method. Drewno 62:53-66. https://doi.org/10.12841/wood.1644-3985.D07

Arora A, Martin EM, Pelkki MH, Carrier DJ (2013) Effect of formic acid and furfural on the enzymatic hydrolysis of cellulose powder and dilute acid-pretreated poplar hydrolysates. ACS Sustain Chem Eng 1:23-28. https://doi.org/10.1021/sc3000702

Balan R, Antczak A, Brethauer S, Zielenkiewicz T, Studer MH (2020) Steam explosion pretreatment of beechwood. Part 1: comparison of the enzymatic hydrolysis of washed solids and whole pretreatment slurry at different solid loadings. Energies 13:3653. https://doi.org/10.3390/en13143653

Ballesteros I, Negro MJ, Oliva JM, Cabańas A, Manzanares P, Ballesteros M (2006) Ethanol production from steam-explosion pretreated wheat straw. Appl Biochem Biotechnol 130:496-508. https://doi. org/10.1385/abab:130:1:496

Berthold J, Salmén L (1997) Inverse size exclusion chromatography (ISEC) for determining the relative pore size distribution of wood pulps. Holzforschung 51:361-368. https://doi.org/10.1515/hfsg.1997. 51.4.361

Brethauer S, Studer MH (2015) Biochemical conversion processes of lignocellulosic biomass to fuels and chemicals-a review. Chimia 69:572-581. https://doi.org/10.2533/chimia.2015.572

Brethauer S, Antczak A, Balan R, Zielenkiewicz T, Studer MH (2020) Steam explosion pretreatment of beechwood. Part 2: quantification of cellulase inhibitors and their effect on Avicel hydrolysis. Energies 13:3638. https://doi.org/10.3390/en13143638

Brownell HH, Saddler JN (1987) Steam pretreatment of lignocellulosic material for enhanced enzymatic hydrolysis. Biotechnol Bioeng 29:228-235. https://doi.org/10.1002/bit.260290213

Brownell HH, Yu EKC, Saddler JN (1986) Steam explosion pretreatment of wood: effect of chip size, acid, moisture content and pressure drop. Biotechnol Bioeng 28:792-801. https://doi.org/10.1002/ bit.260280604

Brun M, Lallemand A, Quinson JF, Eyraud C (1977) A new method for the simultaneous determination of the size and shape of pores: the thermoporometry. Thermochim Acta 21:59-88

Cantarella M, Cantarella L, Gallifuoco A, Spera A, Alfani F (2004) Effect of inhibitors released during steam explosion treatment of poplar wood on subsequent enzymatic hydrolysis and SSF. Biotechnol Prog 20:200-206. https://doi.org/10.1021/bp0257978

Charmas B, Skubiszewska-Zięba J (2017) Application of differential scanning calorimetry to study porous structure of hydrothermally modified silicas. J Therm Anal Calorim 129:23-32. https://doi. org/10.1007/s 10973-017-6126-6

Cullis IF, Saddler JN, Mansfield SD (2004) Effect of initial moisture content and chip size on the bioconversion efficiency of softwood lignocellulosics. Biotechnol Bioeng 85:413-421. https://doi.org/10. 1002/bit.10905

Dinus RJ (2001) Genetic improvement of poplar feedstock quality for ethanol production. Appl Biochem Biotechnol 91:23-34. https://doi.org/10.1385/ABAB:91-93:1-9:23

Dougherty MJ, Tran HM, Stavila V, Knierim B, George A, Auer M, Adams PD, Hadi MZ (2014) Cellulosic biomass pretreatment and sugar yields as a function of biomass particle size. PLoS ONE 9:e100836. https://doi.org/10.1371/journal.pone.0100836 
Drapcho CM, Nhuan NP, Walker TH (2008) Biofuels engineering process technology. McGraw-Hill, New York

Excoffier G, Peguy A, Rinaudo M, Vignon M (1991) Evaluation of lignocellulosic components during steam explosion-potential applications. In: Focher B, Marzetti A, Crescenzi V (eds) Steam explosion techniques: fundamentals and industrial applications. Gordon and Breach Science Publishers, Philadelphia, pp 81-95

Fahlén J, Salmén L (2005) Ultrastructural changes in a holocellulose pulp revealed by enzymes, thermoporosimetry and atomic force microscopy. Holzforschung 59:589-597. https://doi.org/10.1515/HF. 2005.096

Fang H, Deng J, Zhang X (2011) Continuous steam explosion of wheat straw by high pressure mechanical refining system to produce sugars for bioconversion. BioResources 6:4468-4480. https://doi.org/ 10.15376/biores.6.4.4468-4480

Fay JA, Golomb DS (2002) Energy and the environment. Oxford University Press, New York

Grous WR, Converse AO, Grethlein HE (1986) Effect of steam explosion pretreatment on pore size and enzymatic hydrolysis of poplar. Enzyme Microb Technol 8:274-280. https://doi.org/10.1016/01410229(86)90021-9

Guan H, Guiochon G (1996) Study of physico-chemical properties of some packing materials: I. Measurements of the external porosity of packed columns by inverse size-exclusion chromatography. J Chromatogr A 731:27-40. https://doi.org/10.1016/0021-9673(95)01197-8

Guo M, Littlewood J, Joyce J, Murphy R (2014) The environmental profile of bioethanol produced from current and potential future poplar feedstocks in the EU. Green Chem 16:4680-4695. https://doi. org/10.1039/c4gc01124d

Hu F, Ragauskas AJ (2012) Pretreatment and lignocellulosic chemistry. Bioenergy Res 5:1043-1066. https://doi.org/10.1007/s12155-012-9208-0

Imman S, Laosiripojana N, Champreda V (2018) Effects of liquid hot water pretreatment on enzymatic hydrolysis and physicochemical changes of corncobs. Appl Biochem Biotechnol 184:432-443. https://doi.org/10.1007/s12010-017-2541-1

Ishizawa CI, Davis MF, Schell DF, Johnson DK (2007) Porosity and its effect on the digestibility of dilute sulfuric acid pretreated corn stover. J Agric Food Chem 55:2575-2581. https://doi.org/10. 1021/jf062131a

Jerabek K, Revillon A, Puccilli E (1993) Pore structure characterization of organic-inorganic materials by inverse size exclusion chromatography. Chromatographia 36:259-262. https://doi.org/10. 1007/BF02263874

Jönsson LJ, Martín C (2016) Pretreatment of lignocellulose: formation of inhibitory by-products and strategies for minimizing their effect. Bioresour Technol 199:103-112. https://doi.org/10.1016/j. biortech.2015.10.009

Jönsson LJ, Alriksson B, Nilvebrant N-O (2013) Bioconversion of lignocellulose: inhibitors and detoxification. Biotechnol Biofuels 6:16. https://doi.org/10.1186/1754-6834-6-16

Kačik F, Ďurkovič J, Kačiková D (2012) Chemical profiles of wood components of poplar clones for their energy utilization. Energies 5:5243. https://doi.org/10.3390/en5125243

Karimi K, Taherzadeh MJ (2016) A critical review on analysis in pretreatment of lignocelluloses: degree of polymerization, adsorption/desorption, and accessibility. Bioresour Technol 203:348356. https://doi.org/10.1016/j.biortech.2015.12.035

Kim Y, Ximenes E, Mosier NS, Ladisch MR (2011) Soluble inhibitors/deactivators of cellulase enzymes from lignocellulosic biomass. Enzyme Microb Technol 48:408-415. https://doi.org/10. 1016/j.enzmictec.2011.01.007

Ko JK, Kim Y, Ximenes E, Ladisch MR (2015) Effect of liquid hot water pretreatment severity on properties of hardwood lignin and enzymatic hydrolysis of cellulose. Biotechnol Bioeng 112:252-262. https://doi.org/10.1002/bit.25349

Kozłowski T, Babiarz I, Grobelska E (2010) Application of thermoporometry based on convolutive DSC to investigation of mesoporosity in cohesive soils. Arch Hydro-Eng Environ Mech 57:199-218

Krutul D (2002) Exercises in wood chemistry and selected issues in organic chemistry. SGGW Press, Warsaw

Książczak A, Radomski A, Zielenkiewicz T (2003) Nitrocellulose porosity-thermoporometry. J Therm Anal Calorim 74:559-568. https://doi.org/10.1023/B:JTAN.0000005194.70360.c1 
Kumar P, Barrett DM, Delwiche MJ, Stroeve P (2009) Methods for pretreatment of lignocellulosic biomass for efficient hydrolysis and biofuel production. Ind Eng Chem Res 48:3713-3729. https://doi.org/10.1021/ie801542g

Labrecque M, Teodorescu TI (2005) Field performance and biomass production of 12 willow and poplar clones in short-rotation coppice in southern Quebec (Canada). Biomass Bioenergy 29:19. https://doi.org/10.1016/j.biombioe.2004.12.004

Langan P, Petridis L, O’Neill HM, Pingali SV, Foston M, Nishiyama Y, Schultz R, Lindner B, Hanson BL, Harton S, Heller WT, Urban V, Evans BR, Gnanakaran S, Ragauskas AJ, Smith JC, Davison BH (2014) Common processes drive the thermochemical pretreatment of lignocellulosic biomass. Green Chem 16:63-68. https://doi.org/10.1039/C3GC41962B

Li X, Lu J, Zhao J, Qu Y (2014) Characteristics of corn stover pretreated with liquid hot water and fed-batch semi-simultaneous saccharification and fermentation for bioethanol production. PLoS ONE 9:e95455. https://doi.org/10.1371/journal.pone.0095455

Li Z, Fei B, Jiang Z (2015) Effect of steam explosion pretreatment on bamboo for enzymatic hydrolysis and ethanol fermentation. BioResources 10:1037-1047. https://doi.org/10.15376/biores.10.1. 1037-1047

Li M, Cao S, Meng X, Studer M, Wyman CE, Ragauskas AJ, Pu Y (2017) The effect of liquid hot water pretreatment on the chemical-structural alteration and the reduced recalcitrance in poplar. Biotechnol Biofuels 10:237. https://doi.org/10.1186/s13068-017-0926-6

Liu LZ, Blaschek HP (2010) Biomass conversion inhibitors and in situ detoxification. In: Vertès A, Qureshi N, Blaschek H (eds) Biomass to biofules: strategies for global industries. Wiley Press, Hoboken, pp 233-259

Liu Z-H, Qin L, Pang F, Jin M-J, Li B-Z, Kang Y, Dale BE, Yuan Y-J (2013) Effects of biomass particle size on steam explosion pretreatment performance for improving the enzyme digestibility of corn stover. Ind Crop Prod 44:176-184. https://doi.org/10.1016/j.indcrop.2012.11.009

Lu X, Zheng X, Li X, Zhao J (2016) Adsorption and mechanism of cellulase enzymes onto lignin isolated from corn stover pretreated with liquid hot water. Biotechnol Biofuels 9:118. https://doi. org/10.1186/s13068-016-0531-0

Luo C, Brink DL, Blanch HW (2002) Identification of potential fermentation inhibitors in conversion of hybrid poplar hydrolyzate to ethanol. Biomass Bioenergy 22:125-138. https://doi.org/10. 1016/S0961-9534(01)00061-7

Martín-Sampedro R, Martín JA, Eugenio ME, Revilla E, Villar JC (2011) Steam explosion treatment of Eucalyptus globulus wood: influence of operational conditions on chemical and structural modifications. BioResources 6:4922-4935. https://doi.org/10.15376/biores.6.4.4922-4935

Meng X, Foston M, Leisen J, DeMartini J, Wyman CE, Ragauskas AJ (2013) Determination of porosity of lignocellulosic biomass before and after pretreatment by using Simons' stain and NMR techniques. Bioresour Technol 144:467-476. https://doi.org/10.1016/j.biortech.2013.06.091

Michelin M, Teixeira JA (2016) Liquid hot water pretreatment of multifeedstocks and enzymatic hydrolysis of solids obtained thereof. Bioresour Technol 216:862-869. https://doi.org/10.1016/j.biortech. 2016.06.018

Negro MJ, Manzanares P, Oliva JM, Ballesteros I, Ballesteros M (2003) Changes in various physical/ chemical parameters of Pinus pinaster wood after steam explosion pretreatment. Biomass Bioenergy 25:301-308. https://doi.org/10.1016/S0961-9534(03)00017-5

Nunes AP, Pourquie J (1996) Steam explosion pretreatment and enzymatic hydrolysis of eucalyptus wood. Bioresour Technol 57:107-110. https://doi.org/10.1016/0960-8524(96)00019-3

Olsson L, Hahn-Hägerdal B (1996) Fermentation of lignocellulosic hydrolysates for ethanol production. Enzyme Microb Technol 18:312-331

Park S, Venditti RA, Jameel H, Pawlak JJ (2006) Changes in pore size distribution during the drying of cellulose fibers as measured by differential scanning calorimetry. Carbohydr Polym 66:97-103. https://doi.org/10.1016/j.carbpol.2006.02.026

Pfeifer Ch, Cavalli F, Huber B, Theato P, Barner L, Wilhelm M (2021) Investigation of the porosity of poly(sodium methacrylate) hydrogels by ${ }^{1} \mathrm{H}-\mathrm{NMR} \mathrm{T}_{2}$-relaxation and inverse size-exclusion chromatography. Macromol Chem Phys 222:2000300. https://doi.org/10.1002/macp.202000300

Pielhop T, Amgarten J, Rudolf von Rohr P, Studer MH (2016) Steam explosion pretreatment of softwood: the effect of the explosive decompression on enzymatic digestibility. Biotechnol Biofuels 9:152. https://doi.org/10.1186/s13068-016-0567-1

Radomski A (2015) Application of inverse size exclusion chromatography to study the porous structure of lignocellulosic materials. SGGW Press, Warsaw 
Ragauskas A, Williams C, Davison B, Britovsek G, Cairney J, Eckert C, Frederick W, Hallett J, Leak D, Liotta C, Mielenz J, Murphy R, Templer R, Tschaplinski T (2006) The path forward for biofuels and biomaterials. Science 311:484-489. https://doi.org/10.1126/science.1114736

Rahikainen JL, Martin-Sampedro R, Heikkinen H, Rovio S, Marjamaa K, Tamminen T, Rojas OJ, Kruus K (2013) Inhibitory effect of lignin during cellulose bioconversion: the effect of lignin chemistry on non-productive enzyme adsorption. Bioresour Technol 133:270-278. https://doi.org/10.1016/j.biort ech.2013.01.075

Saeman JF, Moore WE, Mitchell RL, Millet MA (1954) Techniques for the determination of pulp constituents by quantitative paper chromatography. TAPPI 37:336-343

Sannigrahi P, Ragauskas AJ, Tuskan GA (2010) Poplar as a feedstock for biofuels: a review for compositional characteristic. Biofuel Bioprod Biorefining 4:209-226. https://doi.org/10.1002/bbb.206

Shevchenko SM, Beatson RP, Saddler JN (1999) The nature of lignin from steam explosion/enzymatic hydrolysis of softwood: structural features and possible uses: scientific note. Appl Biochem Biotechnol 77-79:867-876. https://doi.org/10.1385/abab:79:1-3:867

Simangunsong E, Ziegler-Devin I, Chrusciel L, Girods P, Wistara NJ, Brosse N (2018) Steam explosion of beech wood: effect of the particle size on the xylans recovery. Waste Biomass Valoriz 54:1-9. https://doi.org/10.1007/s12649-018-0522-4

Singh J, Suhag M, Dhaka A (2015) Augmented digestion of lignocellulose by steam explosion, acid and alkaline pretreatment methods: a review. Carbohydr Polym 117:624-631. https://doi.org/10.1016/j. carbpol.2014.10.012

Sluiter A, Ruiz R, Scarlata C, Sluiter J, Templeton D (2008) Determination of extractives in biomass (NREL/TP-510-42619). National Renewable Energy Laboratory, Golden, CO

Sreenath HK, Jeffries TW (2000) Production of ethanol from wood hydrolyzate by yeasts. Bioresour Technol 72:253-260

Stanton BJ, Haiby K, Gantz C, Espinoza J, Shuren RA (2019) The economics of rapid multiplication of hybrid poplar biomass varieties. Forests 10:446-459. https://doi.org/10.3390/f10050446

Strange JH, Mitchell J, Webber JBW (2003) Pore surface exploration by NMR. Magn Reson Imaging 21:221-226. https://doi.org/10.1016/S0730-725X(03)00128-0

Szadkowski J, Szadkowska D (2020) The analysis of the distribution of available mesopores in cellulosic pulp using Inverse Size Exclusion Chromatography-ISEC. Ann WULS-SGGW for Wood Technol 109:103-108. https://doi.org/10.5604/01.3001.0014.3418

Szadkowski J, Radomski A, Szadkowska D, Zakrzewski A, Rębkowski B, Marchwicka M, Lewandowska A (2015) Change in the distribution of available mesopores in the wood of white poplar (Populus alba L.) as a result of cyclic drying. Episteme 26:399-407

Taherzadeh MJ, Karimi K (2007) Enzyme-based hydrolysis processes for ethanol from lignocellulosic materials: a review. BioResources 2:707-738. https://doi.org/10.15376/biores.2.4.707-738

TAPPI T222 om-02 (2006) Acid-insoluble lignin in wood and pulp. TAPPI Press, Atlanta

TAPPI UM 250 (1985) Acid-soluble lignin in wood and pulp. TAPPI Press, Atlanta

Verardi A, De Bari I, Ricca E, Calabrò V (2012) Hydrolysis of lignocellulosic biomass: current status of processes and technologies and future perspectives. In: Lima MAP, Natalense APP (eds) Bioethanol. InTech, Rijeka, pp 95-122

Vermaas JV, Petridis L, Qi X, Schulz R, Lindner B, Smith JC (2015) Mechanism of lignin inhibition of enzymatic biomass deconstruction. Biotechnol Biofuels 8:217. https://doi.org/10.1186/ s13068-015-0379-8

Wise LE, Murphy M, D’Addieco AA (1946) Chlorite holocellulose, its fractionation and bearing on summative wood analysis and on studies on the hemicelluloses. Paper Trade J 122:35-43

Wyman CE, Dale BE, Elander RT, Holtzapple M, Ladisch MR, Lee YY (2005) Coordinated development of leading biomass pretreatment technologies. Bioresour Technol 96:1959-1966. https://doi.org/10. 1016/j.biortech.2005.01.010

Yao Y, Lenhoff AM (2004) Determination of pore size distributions of porous chromatographic adsorbents by inverse size-exclusion chromatography. J Chromatogr A 1037:273-282. https://doi.org/10. 1016/j.chroma.2004.02.054

Zaldivar J, Ingram LO (1999) Effect of organic acids on the growth and fermentation of ethanologenic Escherichia coli LY01. Biotechnol Bioeng 66:203-210. https://doi.org/10.1002/(SICI)1097-0290

Zamora DS, Wyatt GJ, Apostol KG, Tschirner U (2013) Biomass yield, energy values, and chemical composition of hybrid poplars in short rotation woody crop production and native perennial grasses in Minnesota, USA. Biomass Bioenergy 49:222-230. https://doi.org/10.1016/j.biombioe.2012.12. 031 
Zauer M, Kretzschmar J, Großmann L, Pfriem A, Wagenführ A (2014) Analysis of the pore-size distribution and fiber saturation point of native and thermally modified wood using differential scanning calorimetry. Wood Sci Technol 48:177-193. https://doi.org/10.1007/s00226-013-0597-9

Zawadzki J, Szadkowska D, Antczak A, Elbe P, Radomski A, Drożdżek M, Zielenkiewicz T, Kłosińska $\mathrm{T}$ (2015) Effect of furfural on the enzyme activity during enzymatic hydrolysis of cellulose isolated from poplar wood (Populus sp.). Przem Chem 94:1941-1944. https://doi.org/10.15199/62.2015.11.7

Zawadzki J, Radomski A, Antczak A, Kupczyk A (2016) Modern research aspects related to the production of bioethanol from lignocellulosic biomass. In: Karpiński S (ed) Results of selected studies carried out as part of the WOODTECH project. ADAM Press, Warsaw, pp 163-183

Zhao X, Zhang L, Liu D (2012) Biomass recalcitrance. Part I: the chemical compositions and physical structures affecting the enzymatic hydrolysis of lignocellulose. Biofuel Bioprod Biorefining 6:465482. https://doi.org/10.1002/bbb.1331

Zheng Y, Pan Z, Zhang R (2009) Overview of biomass pretreatment for cellulosic ethanol production. Int J Agric Biol Eng 2:51-68. https://doi.org/10.3965/j.issn.1934-6344.2009.03.051-068

Publisher's Note Springer Nature remains neutral with regard to jurisdictional claims in published maps and institutional affiliations. 